Monika Peaziak, Anna Irena Szymańska

Pedagogical University of Cracow, Poland

\title{
Distribution and Activity Growth of Industrial and Construction Sectors in Małopolska Region
}

\begin{abstract}
The paper analyses spatial and dynamic activity of Małopolska Region inhabitants in the industrial and construction sectors on the basis of employment and entrepreneurial activity in these sectors. The years 2006-2011 showed a positive trend for the activity in both sectors, while the performance of the construction sector was significantly better. For comparison for Poland situation was different - the dynamics of employment and entrepreneurial activity in the industry were adverse. As for Poland, entrepreneurial activity in the construction sector intensified, in relative terms, and was relatively high, and substantially higher in the Małopolska Region. Note that a geographic increase in the entrepreneurial attitudes of residents is not followed by any intensified entrepreneurial activity in the construction sector. To the contrary, a reverse trend was observed: the poviats reporting intensive entrepreneurial activity reported a relatively low share of the construction sector and vice versa - the share was rather high in areas reporting the entrepreneurial indicator at its low. Research shows that only a few poviats reported visible unfavourable trends. These are Dąbrowski and Miechowski poviats, which reported a major drop in the number of the employed both in general and specifically in the industrial and construction sector. However, these poviats, considered underdeveloped when compared to the rest of the Region, reported a positive growth of entrepreneurial activity, both in the industry and construction sector, while a downward trend in entrepreneurial activity in the industry was reported in the Suski Poviat as well in more economically advanced and industrialized poviats: Wadowicki and Kraków, what reflects a general national trend.
\end{abstract}

Key words: construction sector; entrepreneurship; industry sector; Małopolska Region

\section{INTRODUCTION}

Contemporary transformations in the global economy, connected with a transfer from the industrial to the information phase in the development of the civilization are reflected in changes which also occur in development of a smaller-scale spatial system, i.e. regional or even local systems. These transformations require some specific adaptation processes, restricting of the economic structure, and changes in the existing spatial and sectorial structures (Rachwał, 2011; Ferudun, Wilczyński, 2013; Kilar, 2010). The economic transformation contributes to widening gaps in the development of country regions. Such changes may 
be also caused by regularly deteriorating activity of work resources resulting from progressing automation and engineering of manufacturing processes (Rachwał, Wiedermann, Kilar, 2009; Zioło, 2001, 2008), evolving employment structure in economic sectors or a growth or shrinking entrepreneurial activity of people who represent work resources.

Economic sectors of particular importance for the economy of Poland are both the industrial and construction sector. In Poland, the industrial sector is in continuous transformation. Automation and innovation reduces employment in industry, while, as presented in this article, employment in the construction sector is growing. However, both sectors play an important role in the economic development of the country. The industry is smoothly engaged in the reproduction process and it also contributes to the implementation of extended reproduction in other areas of the national economy. Industrial activities contribute to close cooperation in several areas, particularly in construction and trade, communications, transport, forestry, agriculture, municipal economy etc. The industry contributes to market balancing, and industrial production for export will be decisive for engagement of the country concerned in the international division of labour, which is an indispensable factor indevelopment of the country (Łukasik, Szopik, 2006: 84; Gierańczyk, Rachwał, 2012). These sectors have strategic importance, impact on the country safety, development and innovation (Wilczyński, 2012, 2013). According to the GDP growth analysis for years 2001-2011, these sectors experienced the most rapid growth at the national scale in 2011. Because of their importance for the economy in Poland and its smooth operation, they have formed the basis of the analyses made by the authors of the article.

This paper has been written to determine the differentiation of spatial distribution of enterprises operating in the industrial and construction sector in the Małopolska Region and identify changes in the distribution in period between 2006-2011 (5 years) - the pre-crisis and the economic crisis. To this end, the authors analysed the share of the working residents in terms of its spatial distribution and growth and measured business activity of residents in the poviats of Małopolska Region in mentioned sectors.

\section{Condition of the industrial and construction Sector in Poland} AND MaŁopolska ReGion

Both the industrial and construction sector in Poland are an important areas of the Polish economy. GBP growth analysis for years 2001-2011 shows that, in 2011, those sectors reported the most rapid growth in Poland.

According to the Main Statistical Office data, the growth rate in the sectors discussed in the paper reached nearly $12 \%$ for the construction sector and more than $6 \%$ for the industrial sector in 2011 (Tab. 1, Fig. 1). 
Tab. 1. GDP growth by economic sectors in Poland in years 2001-2011

\begin{tabular}{|l|r|r|r|r|r|r|r|l|l|l|l|}
\hline Sector/Year & \multicolumn{1}{|c|}{2001} & \multicolumn{1}{|c|}{2002} & 2003 & 2004 & 2005 & 2006 & 2007 & 2008 & 2009 & 2010 & 2011 \\
\hline $\begin{array}{l}\text { GDP } \\
\text { incl.: }\end{array}$ & 101.2 & 101.4 & 103.9 & 105.3 & 103.6 & 106.2 & 106.8 & 105.1 & 101.6 & 103.9 & 104.3 \\
\hline Industry & 99.9 & 99.8 & 108.7 & 110.9 & 103.5 & 109.9 & 110.0 & 106.0 & 101.3 & 109.4 & 106.3 \\
\hline Construction & 97.0 & 92.5 & 97.2 & 101.1 & 106.6 & 112.5 & 109.4 & 105.8 & 111.6 & 106.4 & 111.8 \\
\hline $\begin{array}{l}\text { Trade, car } \\
\text { repairs }\end{array}$ & 102.9 & 103.0 & 99.4 & 103.9 & 104.1 & 104.7 & 104.7 & 106.4 & 104.3 & 102.6 & 104.6 \\
\hline $\begin{array}{l}\text { Transport and } \\
\text { warehouse } \\
\text { management }\end{array}$ & 94.7 & 103.2 & 104.5 & 103.0 & 108.6 & 109.9 & 104.2 & 98.5 & 95.6 & 106.5 & 105.1 \\
\hline
\end{tabular}

Source: own study based on the data from the Main Statistical Office: Informacja o sytuacji społeczno-gospodarczej kraju rok 2011, 2012; Sektor budowlany w czasie i przestrzeni, 2011

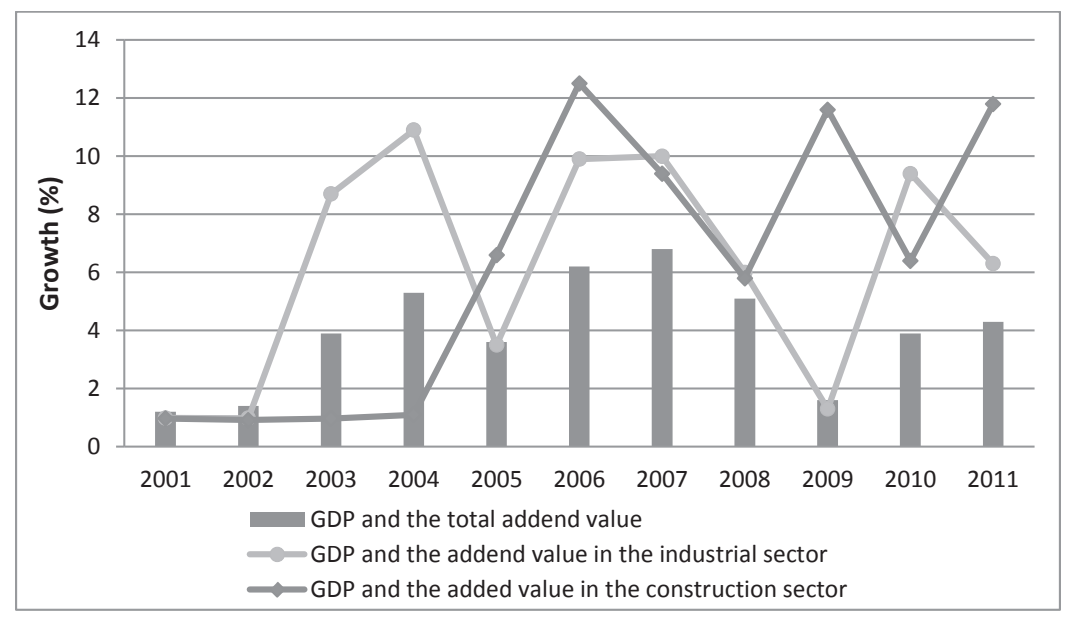

Fig. 1. Growth rate of the annual GBP and gross added value in Polish industry and construction in years 2001-2011

Source: own study based on the data from the Main Statistical Office: Informacja o sytuacji spoleczno-gospodarczej kraju rok 2011, 2012; Sektor budowlany w czasie i przestrzeni, 2011

The value of the GDP generated in the Małopolska Region in 2009 reached PLN 99,509 million and the region came $5^{\text {th }}$ among all Polish regions and $8^{\text {th }}$ in the ranking of regions with the highest GBP per capita. The number of businesses registered in the Małopolska Region in 2011 reached 331,600, i.e. 8.5\% of all the entities registered in Poland. With the above, the Małopolska Region came $4^{\text {th }}$ in the ranking of regions (after Mazovian, Silesian and Greater Poland Regions) with the highest number of registered businesses. When analysing regions by the number of business entities per poviat, the ranking is as follows: Kraków $(116,200$, i.e. $35 \%$ of the total), Krakowski $(25,200-7.6 \%)$, Wadowicki $(15,600-4.7 \%)$, Nowotarski $(14,100-4.3 \%)$, Oświęcimski and Nowosądecki $(13,600-4.1 \%)$. The following poviats came at the bottom of the ranking: Dąbrowski $(2,900-0.9 \%)$ and Proszowicki $(3,600-$ 0.9\%) (Województwo małopolskie 2012. Wojewódzkie studia regionalne, 2012: 122). 
An analysis of business concentration in the Małopolska Region in 2011 showed 99 business entities per 1,000 residents. The highest business entity concentration indicator reported Kraków (153 enterprises), which has the highest number of companies with foreign capital per capita (Raźniak, 2013) and affects the growing global Małopolska capital linkages (Raźniak, Winiarczyk-Raźniak, 2013). Moreover, the high concentration ratio was observed in Tatrzański Poviat (141 enterprises), while the lowest value of the indicator was reported for Tarnowski Poviat (53) and Dąbrowski Poviat (49).

34,400 enterprises in the industrial sector represented as much as $10 \%$ of all business entities registered as such in the region (2011) and a decreasing trend was observed when compared to 2010 figures (for the sake of comparison, in 2010, 34,600 entrepreneurs were registered against 32,600 in 2009 and 33,300 in 2008 and 33,500 in 2007). 13 poviats of the Małopolska Region reported a drop in the number of industrial entities, with the biggest drops in poviats: Suski (120 entities), Wadowicki (96), Olkuski (44) and Nowotarski (35). On the other hand, the number of industrial enterprises in poviats: Kraków (64), Tarnowski (39) and Bocheński (33) went up.

The highest concentration of industrial entities in the Małopolska Region (the number of industrial entities per 1,000 residents in the analysed area) was reported for years for the western part of the Małopolska Region and, specifically, in poviats: Wadowicki (22), Suski(20), Myślenicki (14) and Olkuski (12) (figures of 2011 - Tab. 5).

Since 2009, industrial enterprises in Poland have been reporting improved financial results. The highest growth was reported in industrial processing sector and in energy, gas, water steam and hot water production and supply (Województwo małopolskie 2012. Wojewódzkie studia regionalne, 2012: 154). However, it should be noted that a return on sales (ROS) for enterprises in the industrial sector of the Małopolska Region is slightly lower than the same indicator calculated for the industrial sector in Poland (Fig. 2).

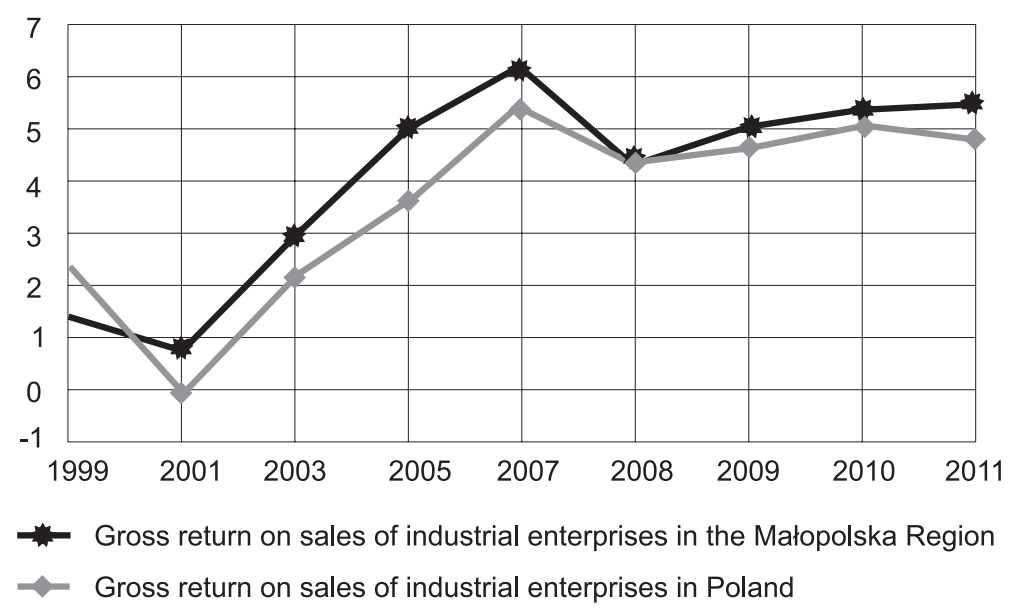

Fig. 2. ROS for industrial enterprises in Poland and the Małopolska Region

Source: own study based on: Województwo matopolskie 2012. Wojewódzkie studia regionalne, 2012: 153 
In 2011, construction enterprises operating in the Małopolska Region represented $13.4 \%$ $(44,400)$ of all registered businesses. In 2011, the value of production sold in the construction sector in Poland reached PLN 188 billion and represented an increase of $17.3 \%$ year-on-year. In the Małopolska Region, the growth was as high as 18.5\% against 2010 (Fig. 3). The percentage share of production sold of the Region against the domestic production sold reached $8.9 \%$ (against $8.8 \%$ in 2010 ).

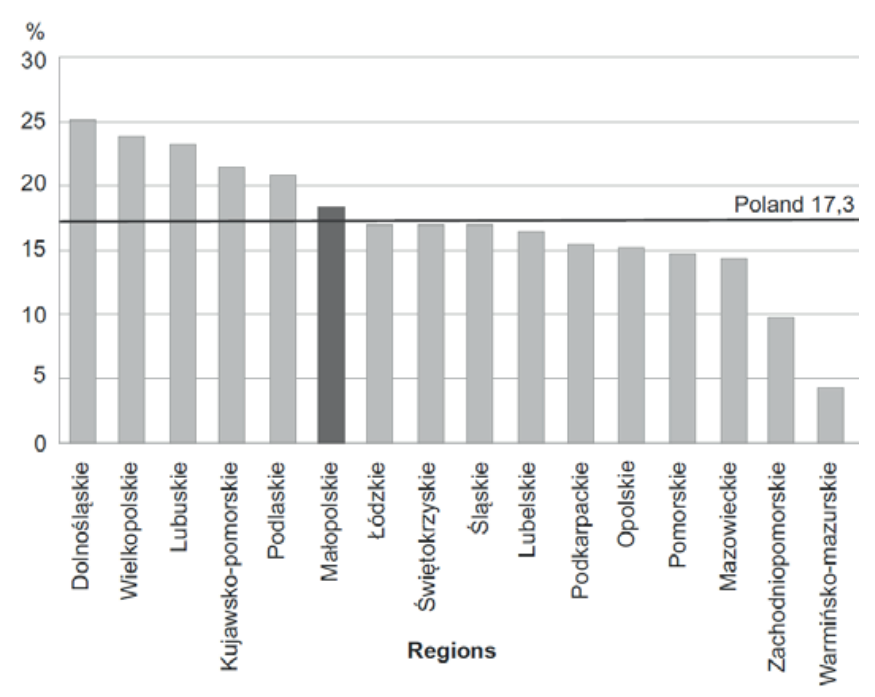

Fig. 3. Growth in production sold of the construction sector in years 2010-2011

Source: own study based on: Województwo małopolskie 2012. Wojewódzkie studia regionalne, 2012: 157

DIFFERENTIATION IN DISTRIBUTION OF INDUSTRIAL AND CONSTRUCTION ENTERPRISES IN THE MAŁoPOLSKA Region For YeARS 2006-2011

The article presents distribution and operational growth in the industrial and construction sector based on the following analyses: 1) an analysis of a spatial distribution of the share of the employed in the analysed sectors to the total number of the employed by poviats in years 2006-2011; 2) spatial distribution of business activity of the Małopolska Region residents in both sectors, expressed by the number of issued REGON business statistical numbers to entities per 1,000 residents by poviats in years 2006-2011. Certainly REGON registration is not an excellent source of statistical information on the current number of economic entities in the country because there are reservations with regard to the virus database update and the adequacy of real business. However, in this type of research it is the most commonly used due to its universality and accessibility. The next source of statistical date used in the analyses was information from the Main Statistical Office. 
The analyses showed a positive growth in the number of persons working in the industry and construction to reach $8.3 \%$ in the period discussed in the paper; however, it was lower than for all the employees as total (11.8\%). The Region reflected a trend which applies to the whole country; still, the growth in the number of all the employed both in the industry and in the construction sector was higher in the Region than for the whole country (Tab. 2). Due to absence of data, it was not possible to determine the growth figure for the number of employees working in both sectors separately for the Małopolska Region.

A similar analysis of entrepreneurship advancement showed a positive growth of $14.6 \%$ against $20.8 \%$ in the analysed industrial and construction sectors. What is interesting, a growth of not more than $2.7 \%$ was reported for the industry and of as much as $39.8 \%$ for the construction sector. All business activity growth indicators: in total for the industry and construction sector and separately for both of them, remained higher for the Małopolska Region than the indicator for the whole country. It is important that, while entrepreneurial activity in Poland in the industrial sector reported a negative growth of $-1.5 \%$ in the analysed period, the Małopolska Region sustained its growing trend of $2.7 \%$. For comparison, the business activity growth in the construction sector was significantly higher, to reach $39.8 \%$, i.e. gain more than the relatively high growth reported for Poland (25.5\%) (Tab. 2).

$T a b .2$. Growth of the employed and business activity in the industry and construction for Poland and the Małopolska Region in years 2006-2011

\begin{tabular}{|c|c|c|c|c|c|c|c|c|}
\hline \multirow{2}{*}{$\begin{array}{c}\text { The } \\
\text { employed/ } \\
\text { REGON } \\
\text { registered } \\
\text { businesses }\end{array}$} & \multicolumn{2}{|c|}{$\begin{array}{c}\text { Total } \\
(\%)\end{array}$} & \multicolumn{2}{c|}{$\begin{array}{c}\text { Industry and } \\
\text { construction (\%) }\end{array}$} & \multicolumn{2}{c|}{$\begin{array}{c}\text { Industry } \\
(\%)\end{array}$} & \multicolumn{2}{c|}{$\begin{array}{c}\text { Construction } \\
(\%)\end{array}$} \\
\cline { 2 - 9 } & Poland & $\begin{array}{c}\text { Małopolska } \\
\text { Region }\end{array}$ & Poland & $\begin{array}{c}\text { Małopolska } \\
\text { Region }\end{array}$ & Poland & $\begin{array}{c}\text { Małopolska } \\
\text { Region }\end{array}$ & Poland & $\begin{array}{c}\text { Małopolska } \\
\text { Region }\end{array}$ \\
\hline Employed & 8.7 & 11.8 & 5.2 & 8.3 & -2.2 & No data & 39.3 & No data \\
\hline $\begin{array}{l}\text { REGON } \\
\text { registered } \\
\text { businesses }\end{array}$ & 6.4 & 14.6 & 11.7 & 20.8 & -1.5 & 2.7 & 25.5 & 39.8 \\
\hline
\end{tabular}

Source: own study based on figures from the Main Statistical Office

Calculation of the share of the employed in the industrial and construction sector in the total number of the employed by poviats in the Małopolska Region made it possible to analyse the employment structure in analysed regions in terms of its spatial distribution (Tab. 3). Table 3 presents both the employment ratio (the share of the employed in the industry and construction in the total number of the employed in years 2006-2011) and the employment growth for years 2006-2011 in the industry and construction, by poviats of the Małopolska Region.

According to the spatial analysis of the Małopolska Region, the share of the employed in the industry and construction sector is higher in the western, traditionally more industrialized part of the Region and changed slightly over the analysed period (Fig. 4). 


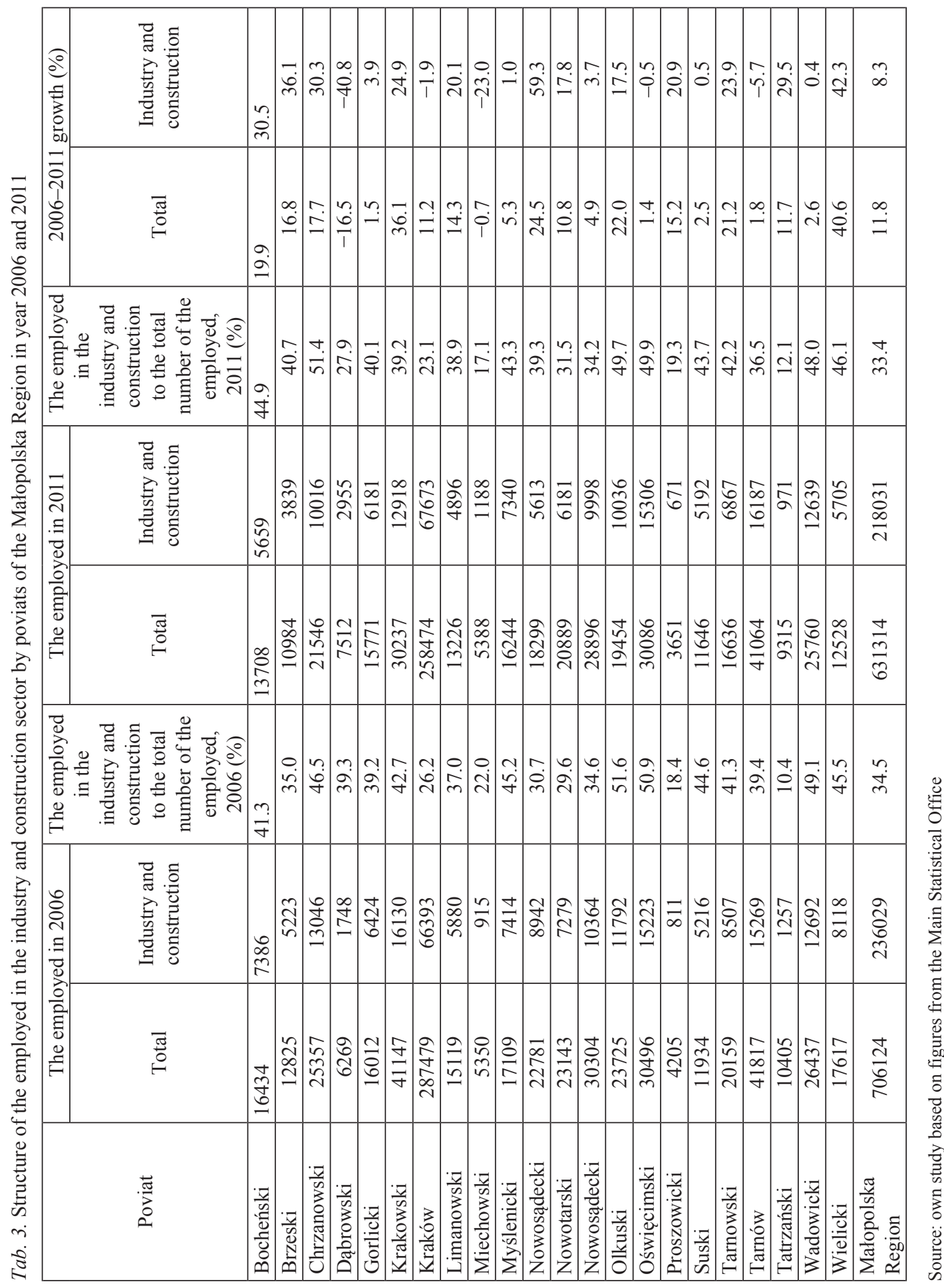




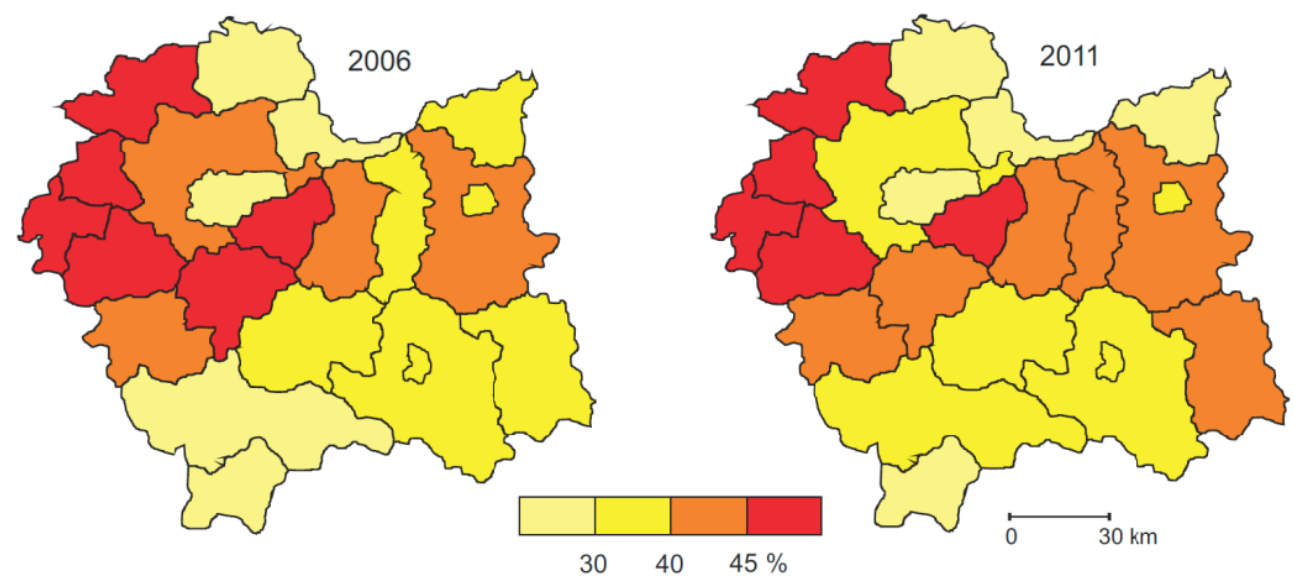

Fig. 4. The share of the employed in the industry and construction sector in the total number of the employed in the Małopolska Region in year 2006 and 2011

Source: own study based on the date from the Main Statistical Office

Generally positive growth of the total employed and a positive growth of the employed in the industry and construction sector was reported. Only poviats: Dąbrowski (-16.5\%) and Miechowski (-0.7\%) are exceptions here, reporting a negative growth of the total employed. For the employed in the industry and construction sector category, five poviats suffered a negative growth: Dąbrowski (-40.8\%), Miechowski (-23.0\%), Tarnowski (-5.7\%), Kraków $(-1.9 \%)$ and Oświęcimski (-0.5\%) (see Tab. 3 and Fig. 4).

There is no doubt that such a significant negative growth in Dąbrowski and Miechowski poviats could be explained by a very low economic growth in these poviats when compared to the growth in the region. There are no large business entities in both poviats. In addition, their peripheral location and poor transport connection to larger urban centres create considerable difficulties for commuting to work outside the poviat. A very low statistical professional activity of Dąbrowski Poviat residents in the working age (49.2\%) means that many unemployed are not registered as the unemployed. Note that the difficult condition of the residents in terms of their economic activity is additionally aggravated by people's considerable engagement in farming. As much as $31 \%$ of the population of Dąbrowski Poviat in the working age work in the farming sector and the indicator ranks near the top of the ranking for the region, following the indicator reported by Proszowicki, Miechowski and Limanowski poviats in the ranking (Charakterystyka zasobów ludzkich..., 2012).

Note that, in the analysed period, the growth in the number of employed in the industrial and construction sector was lower than for the employed in total. Here, the highest growth for the employed in the industrial and construction sector was reported in the following poviats: Nowosądecki (59.3\%), Wielicki (42.3\%), Brzeski (36.1\%), Bocheński(30.5\%) and Chrzanowski (30.3\%) (Tab. 3, Fig. 5). 


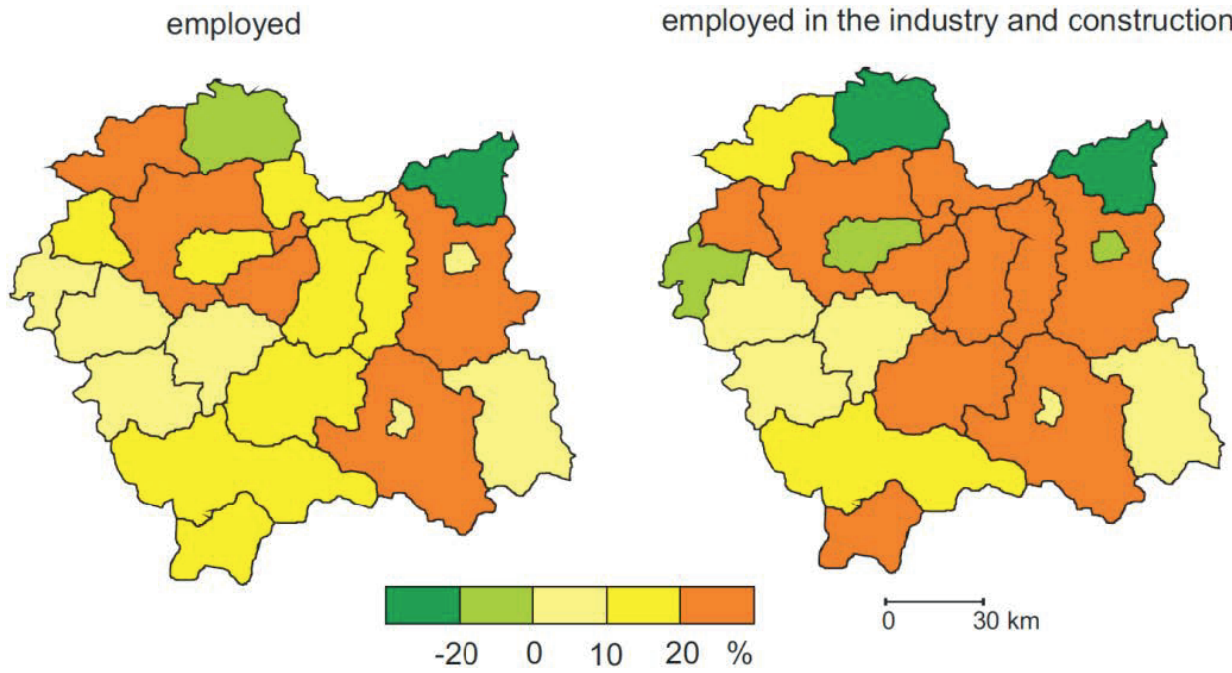

Fig. 5. Growth in the number of all the employed in the Małopolska Region and the employed in the industry and construction in years 2006-2011

Source: own study based on figures from the Main Statistical Office

To analyse entrepreneurial activity in the industrial and construction sector for the Małopolska Region residents, an entrepreneurial activity indicator for all enterprises was calculated as well as an indicator for industrial and construction enterprises. Their values clearly indicate a significant growth in the entrepreneurial activity in general from $88.5 \%$ to $98.3 \%$ in the analysed period. What is significant, the value of the indicator for the industrial sector in the analysed period did not change and reached $10.2 \%$ in both analysed years. On the other hand, a visible growth in the indicator for the construction sector was reported: from $9.7 \%$ in 2006 to $13.2 \%$ in 2011 (Tab. 4).

Tab. 4. Entrepreneurial activity of the Małopolska Region residents in total and in the industrial and construction sector by poviats in year 2006 and 2011

\begin{tabular}{|c|c|c|c|c|c|}
\hline \multicolumn{2}{|c|}{$\begin{array}{c}\text { Total REGON registered } \\
\text { business entities } \\
\text { per } 1,000 \text { residents }\end{array}$} & \multicolumn{2}{|c|}{$\begin{array}{c}\text { Total REGON registered } \\
\text { industrial sector entities } \\
\text { per } 1,000 \text { residents }\end{array}$} & \multicolumn{2}{|c|}{$\begin{array}{c}\text { Total REGON registered } \\
\text { construction sector entities } \\
\text { per } 1,000 \text { residents }\end{array}$} \\
\hline 2006 & 2011 & 2006 & 2011 & 2006 & 2011 \\
\hline 88.5 & 98.3 & 10.2 & 10.2 & 9.7 & 13.2 \\
\hline
\end{tabular}

Source: own study based on figures from the Main Statistical Office

A spatial analysis of the entrepreneurial activity indicator disclosed a division of the Małopolska Region into its western, more entrepreneurial part and its eastern and southern parts, which are less active, with the exception of the Tatrzański Poviat, reporting a relatively high entrepreneurial activity indicator due to its traditionally high tourist activity (Tab. 5, Fig. 6). 


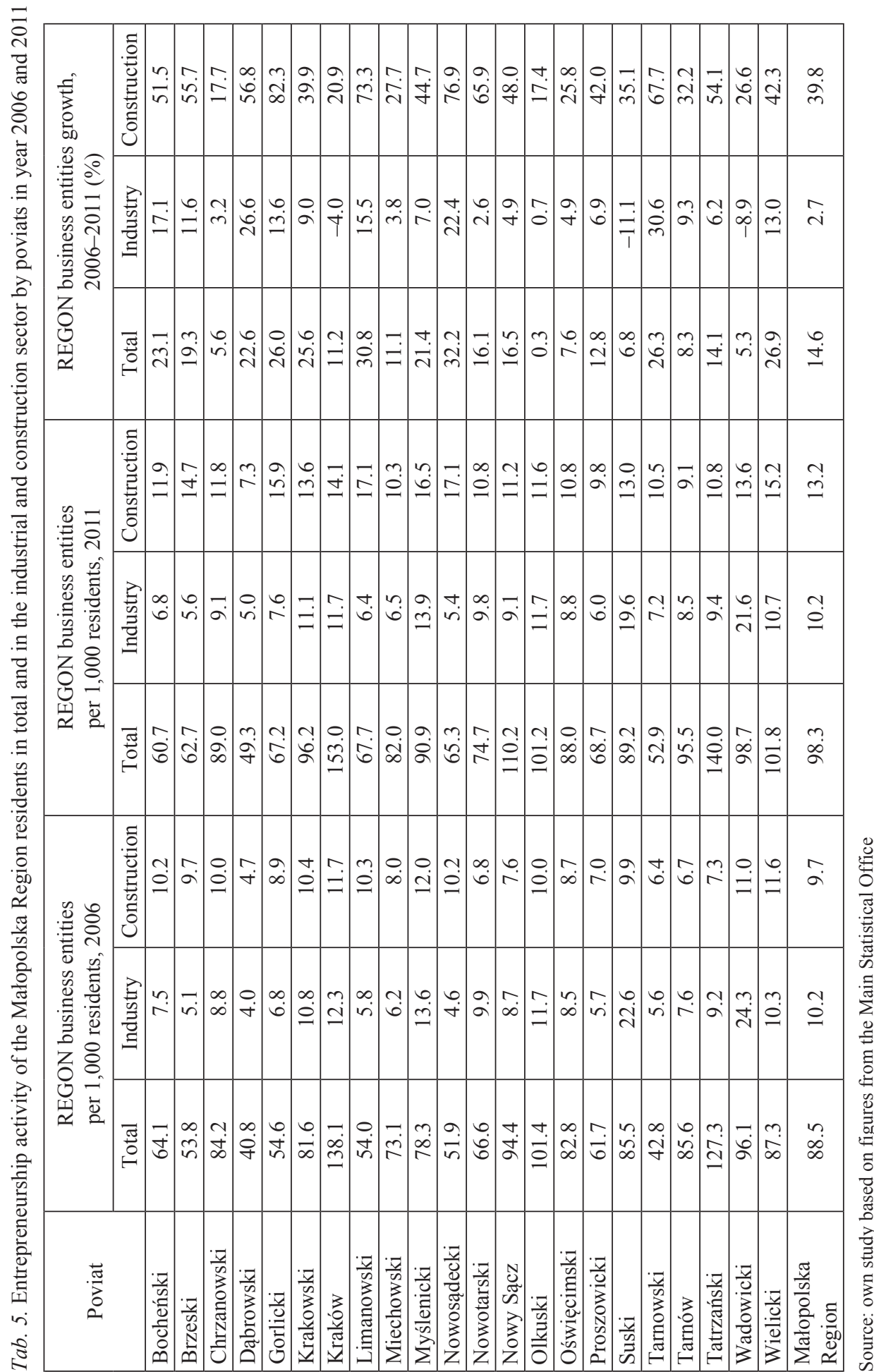


In both two analysed years: 2006 and 2011, the highest business activity indicator reported Kraków, the largest entrepreneurial activity centre in the Region, what is reflected in the high level of societal security recorded in the city (Raźniak, Winiarczyk-Raźniak, 2014). Poviats traditionally considered more industrialized, economically advanced and more urbanized typically report higher values of the indicator.
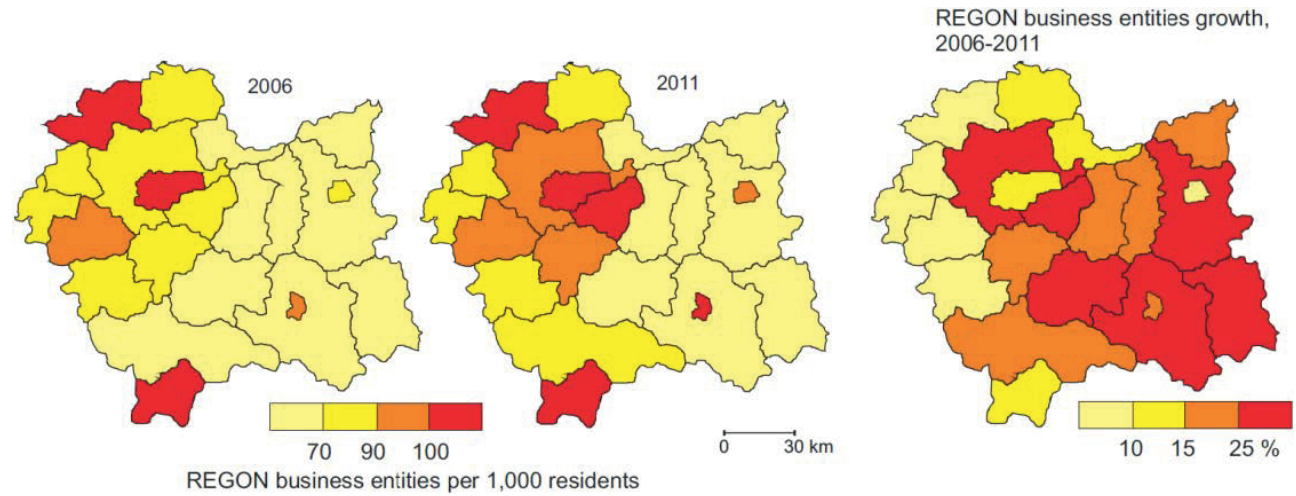

Fig. 6. Business and entrepreneurial activity of the Małopolska Region residents in years 2006-2011

Source: own study based on figures from the Main Statistical Office

However, a dynamic analysis of entrepreneurship advancement showed that the growth in the number of business entities was the highest in poviats reporting a relatively low total entrepreneurial activity ratio (except for Wielicki Poviat, which reported both high entrepreneurial activity and its rapid growth). On the other hand, the entities reporting rather high or medium-level indicators, showed the lowest business activity growth. These were all western poviats of described region (Tab. 5, Fig. 6).

Spatial distribution of the entrepreneurial activity indicator for the Małopolska Region residents in the industry reflects the division of the Region into a more industrialized, western part and its less industrialized, eastern part. And the highest growth of industrial business activity of the residents was reported in less industrialized poviats, i.e. Tarnowski $(30.6 \%)$, Dąbrowski (26.6\%), Nowosądecki (22.4\%), Bocheński (17.1\%) and Limanowski (15.5\%). All poviats in the western and southern part of the Małopolska Region show low growth; for 3 of them the growth was negative: Suski (-11.1\%), Wadowicki (-8.9\%) and Kraków $(-4.0 \%)$. However, they showed high or the highest entrepreneurial activity indicators in the industry sector (Fig. 7).

While 3 entities reported negative growth of business in the industrial sector and the highest growth fluctuated from 15 to $30 \%$, a positive growth of the construction business was reported for all poviats and some boasted a growth as high as $60 \%$ and more (Tab. 5, Fig. 8).

Analysing entrepreneurial activity of residents in the construction sector it should be noticed that poviats of the central and south-eastern part of the Region demonstrated the highest activity in this field and the high and the highest growth was reported for the entire part of the Region and south-eastern poviats in particular. The lowest, but relatively 
considerable, growth in the number of construction businesses was reported for 2 typically industrial poviats: Olkuski (17.4) and Chrzanowski (17.7). As mentioned above, the highest growth indicator in excess of $60 \%$ was reported in poviats: Gorlicki (82.3), Nowosądecki (76.9), Limanowski (74.3), Tarnowski (67.7) and Nowotarski (65.9). They boast a long tradition of setting up small, family construction businesses (often in response to lack of jobs in the industrial sector and overpopulation in the farming sector) which operate not only in their immediate neighbourhood but also in the whole region and outside the region, supplying labour force, which is commonly believed cheap (Szymańska, Płaziak, 2014).

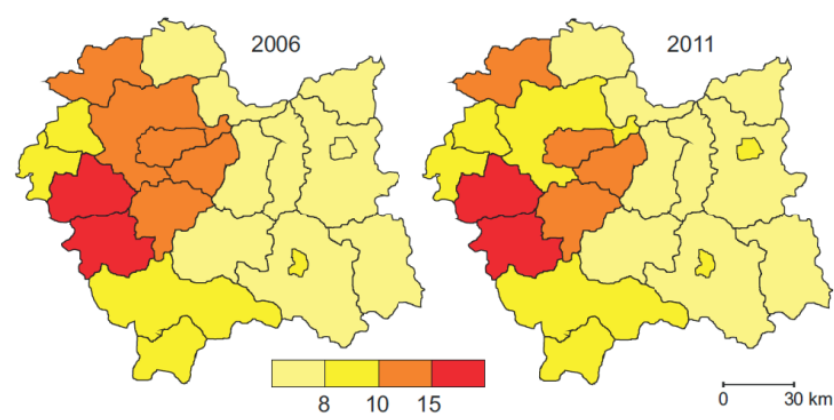

REGON industrial business entities per 1,000 residents
REGON industrial business entities growth, 2006-2011

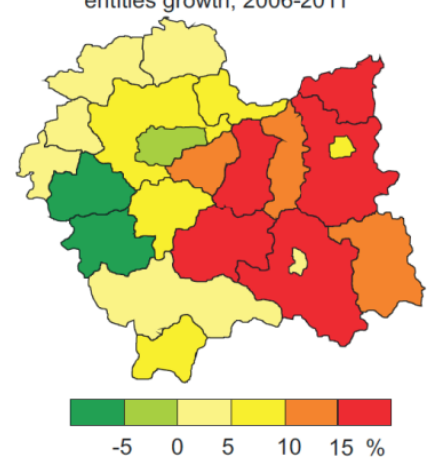

Fig. 7. Entrepreneurial activity of the Małopolska Region residents in the industrial sector in years 2006-2011

Source: own study based on figures from the Main Statistical Office
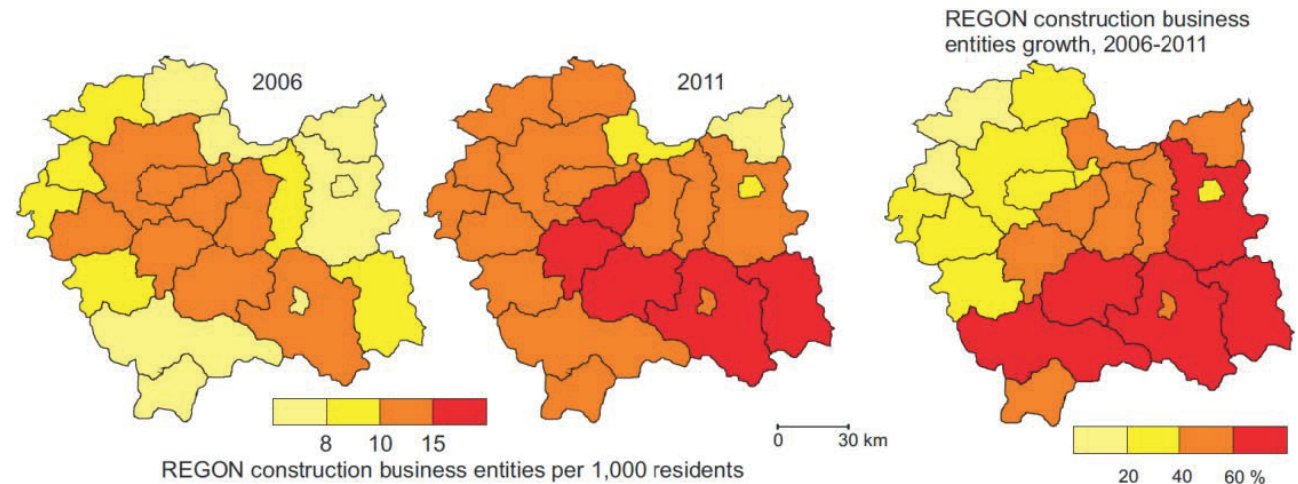

Fig. 8. Entrepreneurial activity of the Małopolska Region residents in the construction sector in years 2006-2011

Source: own study based on figures from the Main Statistical Office 


\section{Conclusions}

When compared to the rest of Poland, the Małopolska Region demonstrates higher activity of its residents in the industrial and construction sector, both by share of the employed and transacting business in both sectors. While in the analysed period of 2006-2011, a negative growth of the employed and entrepreneurial activity in the industry was reported for Poland, the Małopolska Region maintained a growing trend in the industrial sector operations (due to lack of statistical data for the employed in the industry, this could not be clearly determined). A particularly rapid growth was reported for business operations in the construction sector and the growing trend was higher than for Poland.

The Region is characterized by a stable growing trend in business, significantly above the national average and, as mentioned above, the trend is particularly visible in the constructions sector. Still, according to the analysis, a geographic increase in the entrepreneurial attitudes of residents is not followed by any increased entrepreneurial activity in the construction sector. To the contrary, a reverse trend was fund: in poviats reporting advanced entrepreneurship, the share of the construction sector was relatively low and vice versa - it was rather high in areas reporting the entrepreneurial indicator at its low. "Less entrepreneurial" poviats in the south-eastern part of the Region tend to specialize in construction, which is a resultant of a low, when compared to the rest of the region, development of the enterprise agglomeration factor, as well as the absence of any other specialisation in the area, e.g. tourism, as it is the case in Tatrzański Poviat. The fact that entrepreneurs from the south-eastern part of the region (in particular: Nowosądecki, Limanowski, Gorlicki and Brzeski poviats) specialise in construction industry results from a lack of alternative employment options. The construction enterprises' size structure indicates that micro and small enterprises prevail, which is related to a large share of the self-employed in that particular sector. As proved by previous research of the authors (Szymańska, Płaziak, 2014), the tradition of construction businesses operating in south-eastern parts of the Małopolska Region is not directly related to a potential sales market in the area but more with absence of alternative employment opportunities, as indicated above.

Summarizing, the Małopolska Region reports a growing trend in the number of the employed and the number of businesses both in general and, specifically, in the industrial and construction sectors. Only some poviats reported unfavourable trends, including, in particular, Dąbrowski and Miechowski poviats, which reported a major drop in the number of the employed both in general and specifically in the industrial and construction sector. However, these poviats, considered underdeveloped when compared to the rest of the Region, reported a positive growth of general business, as well as a positive growth in the industry and construction. The industrial sector activities in the Suski Poviat did not report any growth either, and the same trend was presented in more economically developed and industrialized units: Wadowicki Poviat and Kraków, again reporting a negative growth, reflecting the national trend. 


\section{References}

Charakterystyka zasobów ludzkich Małopolski. Powiat Dąbrowski. (2012). Kraków: Wojewódzki Urząd Pracy w Krakowie.

Ferudun, D., Wilczyński, P.L. (2013). The Similarity Analysis of Industrial Development in EU Countries and Turkey Using Hierarchical Cluster Technique. Prace Komisji Geografii Przemystu Polskiego Towarzystwa Geograficznego, 21, 316-326.

Gierańczyk, W., Rachwał, T. (2012). Structural changes in the industry of Poland against the background of eastern European Union states. Quaestiones Geographicae, 31(2), 83-93.

Kilar, W. (2010). Zmiany potencjału korporacji informatycznych w Unii Europejskiej w latach 20042008. Przedsiębiorczość - Edukacja, 6, 49-65.

Łukasik, W., Szopik, K. (2006). Istota, zakres i cele działalności przemysłowej. In: W. Janasz (ed.), Zarys strategii rozwoju przemystu. Warszawa: Difin, 60-85.

Informacja o sytuacji społeczno-gospodarczej kraju, rok 2011, 2012. Warszawa: GUS.

Rachwał, T., Wiedermann, K., Kilar, W. (2009). Rola przemysłu w gospodarce układów regionalnych Unii Europejskiej. Prace Komisji Geografii Przemystu Polskiego Towarzystwa Geograficznego, $14,31-42$.

Rachwał, T. (2011). Industrial restructuring in Poland and other European Union states in the era of economic globalization. Procedia - Social and Behavioral Sciences, 19, 1-10.

Raźniak, P. (2013). Procesy suburbanizacyjne w regionie miejskim Krakowa na tle rozwoju społecznogospodarczego województwa małopolskiego. In: P. Raźniak (ed.), Społeczno-ekonomiczne przemiany regionów. Kraków: Oficyna Wydawnicza AFM, 45-66.

Raźniak, P., Winiarczyk-Raźniak, A. (2013). Spatial distribution and differences in migration patterns and revenues of gminas in the Kraków Metropolitan Area. Bulletin of Geography. Sociooeconomic Series, 19, 73-86.

Raźniak, P., Winiarczyk-Raźniak, A. (2014). Influence of the societal security level on population migrations in Poland. Procedia - Social and Behavioral Sciences, 120, 2-12.

Sektor budowlany $w$ czasie i przestrzeni. Ocena standingu adaptacyjności sektora. (2011). Grupa Doradców Biznesowych BAA Polska.

Szymańska, A.I., Płaziak, M. (2014). Factors considered in location of construction enterprises in the Małopolska Region. Procedia - Social and Behavioral Sciences, 110, 381-389.

Województwo matopolskie 2012. (2012). Wojewódzkie studia regionalne. Kraków: Departament Polityki Regionalnej, Urząd Marszałkowski Województwa Małopolskiego.

Wilczyński, P.L. (2013). Sektor zbrojeniowy jako czynnik rozwoju gospodarki opartej na wiedzy. Prace Komisji Geografii Przemystu Polskiego Towarzystwa Geograficznego, 21, 133-156.

Wilczyński, P.L. (2012). Innowacje w zbrojeniach i obronności jako katalizator przemian technologicznych. Prace Komisji Geografii Przemystu Polskiego Towarzystwa Geograficznego, 20, 124-133.

Zioło, Z. (2008). Procesy transformacji przemysłowych układów przestrzennych na tle zmieniającego się otoczenia. Prace Komisji Geografii Przemystu Polskiego Towarzystwa Geograficznego, 10, $11-22$.

Zioło, Z. (2001). Współczesne tendencje rozwoju przemysłu i ich problematyka badawcza. Prace Komisji Geografii Przemystu Polskiego Towarzystwa Geograficznego, 2, 9-20.

Monika Plaziak, Ph.D. degree in economic geography, assistant professor in the Department of Entrepreneurship and Spatial Management, Institute of Geography, Pedagogical University of Cracow. Author's research interests concern issues of the spatial development in the context of the sustainable development - social balanced towns and energy-efficient towns, and also process of industrial and construction enterprises locations. Her research works refer to issues of the cooperation of scientific and research-developmental organizations with the SME sector, especially in the matter of the implementing new technologies and materials concerning the energy-efficient and passive building. 
Additionally, the author analyses issues of the level and quality of life, with particular reference to small and medium-sized towns in Poland.

Anna Irena Szymańska, graduated from University of Economics in Krakow, MA degree in Management and Marketing, Ph.D. degree in economic sciences in the field of management sciences (Chair of Market Analysis and Marketing Research - University of Economics in Cracow), assistant professor in the Department of Entrepreneurship and Spatial Management, Institute of Geography, Pedagogical University of Cracow. Her research interests are related to the issue of consumer needs, preferences and market behaviour as well as issues in the area of entrepreneurship and innovation with particular emphasis on the SME sector.

\section{Adres/address:}

Monika Płaziak, Anna Irena Szymańska

Pedagogical University of Cracow

Department of Entrepreneurship and Spatial Management

Institute of Geography

ul. Podchorążych 2, 30-084 Kraków, Poland

e-mail:mplaziak@up.krakow.pl

aszym@up.krakow.pl 